\title{
Stereoselective Synthesis of the C(1)-C(11) Fragment of Peloruside A
}

\author{
Robert M. Owen and William R. Roush*† \\ Department of Chemistry, University of Michigan, Ann Arbor, MI 48109 \\ Email: roush@umich.edu
}

† Current Address: Scripps Florida, Medicinal Chemistry

5353 Parkside Drive, RF-2, Jupiter, FL 33458

e-mail: roush@scripps.edu

Supporting Information - Experimental Details 
General Experimental Details. All reaction solvents were purified before use. Tetrahydrofuran (THF), dichloromethane $\left(\mathrm{CH}_{2} \mathrm{Cl}_{2}\right)$, and diethyl ether $\left(\mathrm{Et}_{2} \mathrm{O}\right)$ were purified by passing through a solvent column composed of activated A-1 alumina. Triethylamine $\left(\mathrm{Et}_{3} \mathrm{~N}\right)$, pyridine and 2,6-lutidine were distilled from calcium hydride. All reactions that are sensitive to moisture or oxygen were conducted under an atmosphere of nitrogen or argon in flame-dried glassware. Unless otherwise indicated, all reagents and solvents were used as purchased without further purification. The term "concentrated under reduced pressure" refers to the removal of solvents and other volatile materials using a rotary evaporator at water aspirator pressure $(<20$ torr) while maintaining the water bath temperature below $40{ }^{\circ} \mathrm{C}$, followed by residual solvent removal at high vacuum $(<0.1$ torr $)$.

Proton nuclear magnetic resonance $\left({ }^{1} \mathrm{H}\right.$ NMR $)$ spectra and carbon-13 $\left({ }^{13} \mathrm{C}\right.$ NMR $)$ spectra were recorded on a Varian Inova-500 spectrometer at $500 \mathrm{MHz}$ and $125 \mathrm{MHz}$ respectively. The proton signal of residual, non-deuterated solvent $\left(\square 7.27 \mathrm{ppm}\right.$ for $\left.\mathrm{CHCl}_{3}\right)$ was used as an internal reference for ${ }^{1} \mathrm{H}$ NMR spectra. For ${ }^{13} \mathrm{C}$ NMR spectra, chemical shifts are reported relative to the $77.0 \mathrm{ppm}$ resonance of $\mathrm{CDCl}_{3}$. Coupling constants are reported in $\mathrm{Hz} .{ }^{1} \mathrm{H}$ NMR data are assumed to be first order, and obvious $\mathrm{AB}$ and $\mathrm{ABX}$ patterns are designated as such for clarity. Infrared (IR) spectra were recorded as thin films on a Perkin-Elmer Spectrum 1000 FTIR. Mass spectra were recorded on a ZVG 70-250-S spectrometer manufactured by Micromass Corp. (Manchester UK). Analytical thin layer chromatography (TLC) was performed on Kieselgel $60 \mathrm{~F}$ 254 glass plates precoated with a $0.25 \mathrm{~mm}$ thickness of silica gel. The TLC plates were visualized with UV light and/or by staining with Hanessian's stain $\left(\mathrm{CeSO}_{4} /\left(\mathrm{NH}_{4}\right) \mathrm{Mo}_{7} \mathrm{O}_{24}\right.$ in $\mathrm{H}_{2} \mathrm{SO}_{4} / \mathrm{H}_{2} \mathrm{O}$ ). Column chromatography was performed using Kieselgel 60 (230-400 mesh) silica gel.

HPLC purifications were performed by using a HPLC system composed of two Rainin HPXL pumps connected to various Dynamax ${ }^{\circledR}$ axial compression columns packed with $60 \AA$ irregular silica gel. Samples were loaded into the system with a $2 \mathrm{~mL}$ Rheodyne 7125 injector and were detected using either a Rainin Dynamax ${ }^{\circledR}$ UV-C detector or a Dynamax ${ }^{\circledR}$ RI-1 detector. 


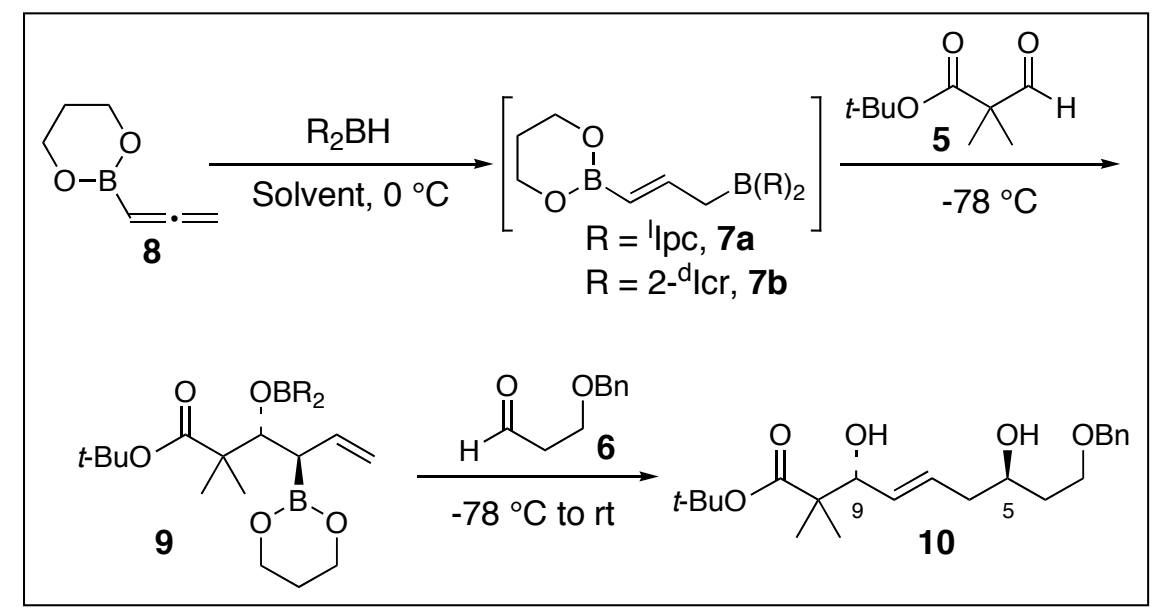

Diol 10: Allene $\mathbf{8}^{1}$ (745 mg, $\left.6.01 \mathrm{mmol}\right)$ was added to a suspension of $\left({ }^{1} \mathrm{Ipc}\right)_{2} \mathrm{BH}^{2}(1.72 \mathrm{~g}, 6.01$ mmol) in $\mathrm{CH}_{2} \mathrm{Cl}_{2}(10 \mathrm{~mL})$ at $0{ }^{\circ} \mathrm{C}$. The suspension was stirred at $0{ }^{\circ} \mathrm{C}$ for $1.5 \mathrm{~h}$ and then warmed to room temperature at which time it became homogeneous. This solution was cooled to $-78{ }^{\circ} \mathrm{C}$, and a solution of aldehyde $5^{3}(511 \mathrm{mg}, 2.97 \mathrm{mmol})$ in $\mathrm{CH}_{2} \mathrm{Cl}_{2}(2 \mathrm{~mL})$ was slowly added down the side of the flask. This solution was stirred for $5 \mathrm{~h}$ at $-78{ }^{\circ} \mathrm{C}$, then aldehyde $6^{4}$ was added dropwise, and the resulting mixture was allowed to stir at room temperature for ca. $24 \mathrm{~h}$. This reaction mixture was then poured into a suspension of THF $(20 \mathrm{~mL})$, water $(30 \mathrm{~mL})$ and $\mathrm{MeOH}(10 \mathrm{~mL})$ containing sodium perborate $(3.5 \mathrm{~g}, 35 \mathrm{mmol})$ with $10 \mathrm{~mL}$ of THF to aid the transfer. After the mixture was vigorously stirred for $3 \mathrm{~h}$ at room temperature, it was diluted with $\mathrm{Et}_{2} \mathrm{O}$ and water, and the organic layer was washed with brine and dried $\left(\mathrm{MgSO}_{4}\right)$. Concentration of the filtered solution under reduced pressure and purification of the crude material via column chromatography $\left(\mathrm{SiO}_{2}, 4: 1 \mathrm{Et}_{2} \mathrm{O}\right.$-hexanes $\rightarrow$ 1:1

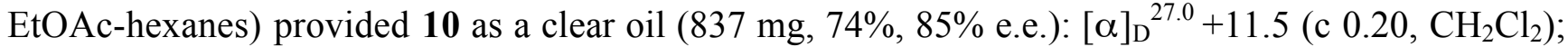
${ }^{1} \mathrm{H}$ NMR $\left(500 \mathrm{MHz}, \mathrm{CDCl}_{3}\right) \square$ 7.37-7.27 (m, 5H), $5.74(\mathrm{dt}, \mathrm{J}=15.0,7.0 \mathrm{~Hz}, 1 \mathrm{H}), 5.56(\mathrm{dd}, \mathrm{J}=15.5$, $7.0 \mathrm{~Hz}, 1 \mathrm{H}), 4.53(\mathrm{~s}, 2 \mathrm{H}), 4.08(\operatorname{app~t}, \mathrm{J}=6.0 \mathrm{~Hz}, 1 \mathrm{H}), 3.88(\mathrm{bp}, \mathrm{J}=5.5 \mathrm{~Hz}, 1 \mathrm{H}), 3.74-3.62(\mathrm{~m}, 2 \mathrm{H})$, 2.95 (br s, 1H), 2.90 (d, J = 5.5 Hz, 1H), 2.25 (t, J = 6.5 Hz, 2H), 1.79-1.74 (m, 2H), 1.46 (s, 9H), 1.15 (s, 3H), $1.12(\mathrm{~s}, 1 \mathrm{H}) ;{ }^{13} \mathrm{C}$ NMR $\left(125 \mathrm{MHz}, \mathrm{CDCl}_{3}\right) \square 176.7,137.9,131.3,129.9,128.4,127.7$, 127.6, $80.9,77.7,73.3,70.4,68.9,47.0,40.4,35.9,28.0,22.5,20.4$; IR (thin film, NaCl) 3436, 3089, 3064, 3031, 2977, 2934, 2872, 1725, 1496, 1470, 1455, 1392 ,1368, 1277, 1255, 1207, 1158, 1117, 1028, 974, 900, 851 , $738,698 \mathrm{~cm}^{-1}$; HRMS (ESI) $401.2304 \mathrm{~m} / \mathrm{z}$ [calc $\left.\mathrm{M}+\mathrm{Na}^{+} \mathrm{C}_{22} \mathrm{H}_{34} \mathrm{O}_{5} \mathrm{Na} 401.2304\right]$.

${ }^{1}$ Flamme, E. M.; Roush, W. R. J. Am. Chem. Soc. 2002, 124, 13644.

${ }^{2}$ Brown, H. C.; Singaram, B. J. Org. Chem. 1984, 49, 945.

${ }^{3}$ (a) Asari, T.; Ishikawa, S.; Sasaki, T.; Katada, J.; Hayashi, Y.; Harada, T.; Yano, M.; Yasuda, E.; Uno, I.; Ojima, I. Bioorg. Med. Chem. Lett. 1997, 7, 2099.(b) Chiba, T.; Sakaki, J.; Takahashi, T.; Aoki, K.; Kamiyama, A.; Kaneko, C.; Sato, M. J. Chem. Soc. Perkin Trans. I 1987, 1, 1845.

${ }^{4}$ Overman, L. E.; Bell, K. L.; Ito, F. J. Am. Chem. Soc. 1984, 106, 4192. 
The enantiomeric purity and absolute configuration of compound $\mathbf{1 0}$ were determined by ${ }^{1} \mathrm{H}$ NMR analysis of the bis-Mosher ester: ${ }^{5}$
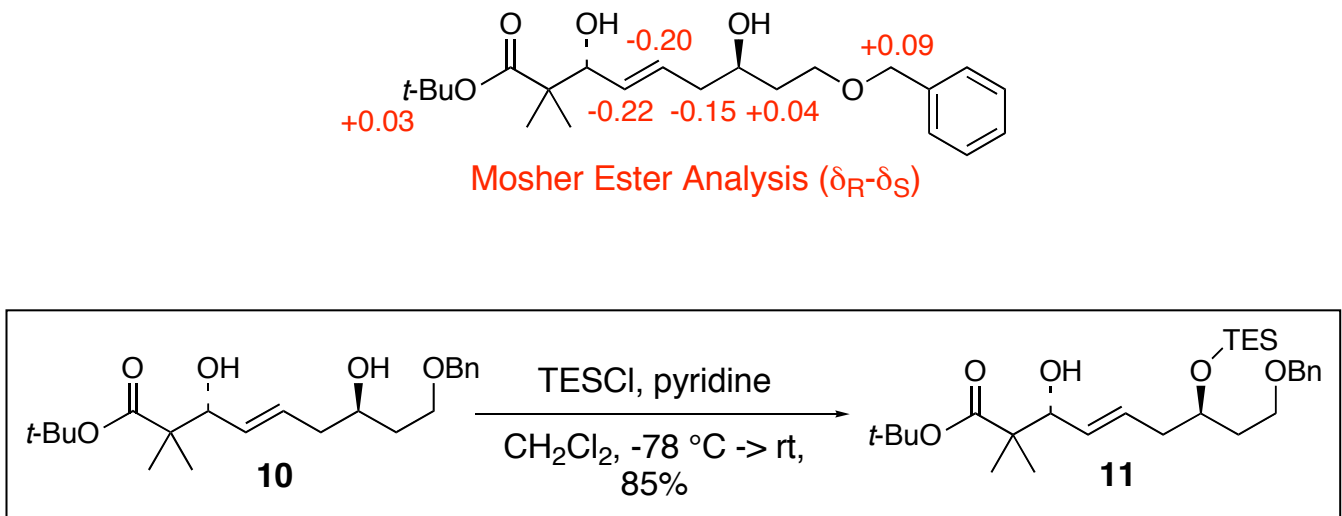

Alcohol 11: Diol 10 (676 mg, $1.79 \mathrm{mmol})$ was dissolved in $\mathrm{CH}_{2} \mathrm{Cl}_{2}(20 \mathrm{~mL})$, pyridine $(290 \mu \mathrm{L}$, $3.58 \mathrm{mmol}$ ) was added and the solution was cooled to $-78^{\circ} \mathrm{C}$. A solution of triethylsilyl chloride (340 $\mu \mathrm{L}, 2.00 \mathrm{mmol})$ dissolved in $\mathrm{CH}_{2} \mathrm{Cl}_{2}(5 \mathrm{~mL})$ was cooled to $-78{ }^{\circ} \mathrm{C}$ and then slowly added to the above solution via a teflon cannula. The reaction mixture was stirred overnight while slowly warming to room temperature. After this time, the solution was diluted with $\mathrm{Et}_{2} \mathrm{O}$ and water and the organic layer was washed with water, saturated $\mathrm{NaHCO}_{3}$ and brine and then dried $\left(\mathrm{MgSO}_{4}\right)$. Concentration of the filtered solution under reduced pressure and purification of the crude mixture via column

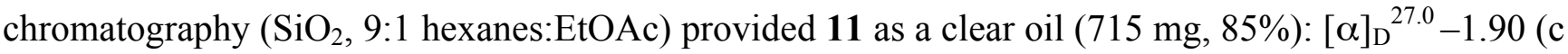
2.34, $\left.\mathrm{CH}_{2} \mathrm{Cl}_{2}\right)$; ${ }^{1} \mathrm{H}$ NMR (500 MHz, $\left.\mathrm{CDCl}_{3}\right) \square 7.37-7.27(\mathrm{~m}, 5 \mathrm{H}), 5.74(\mathrm{dt}, \mathrm{J}=15.5,7.5 \mathrm{~Hz}, 1 \mathrm{H}), 5.50$ $(\mathrm{dd}, \mathrm{J}=15.5,7.0 \mathrm{~Hz}, 1 \mathrm{H}), 4.49(\mathrm{AB}, \mathrm{J}=12.0 \mathrm{~Hz}, 2 \mathrm{H}), 4.07$ (br t, J = 5.5 Hz, 1H), 3.93 (m, 1H), 3.54 (m, 2H), 2.77 (br s, 1H), $2.25(\mathrm{~m}, 2 \mathrm{H}), 1.80(\mathrm{~m}, 1 \mathrm{H}), 1.70(\mathrm{~m}, 1 \mathrm{H}), 1.46(\mathrm{~s}, 9 \mathrm{H}), 1.14(\mathrm{~s}, 3 \mathrm{H}), 1.12(\mathrm{~s}$, $3 \mathrm{H}), 0.96(\mathrm{t}, \mathrm{J}=8.0 \mathrm{~Hz}, 9 \mathrm{H}), 0.60$ (q, J = 7.5 Hz, 6H); ${ }^{13} \mathrm{C} \mathrm{NMR}\left(125 \mathrm{MHz}, \mathrm{CDCl}_{3}\right) \square 176.7,138.5$, $130.7,130.1,128.3,127.6,127.5,80.8,77.8,72.9,68.9,66.9,47.0,40.9,36.8,28.0,22.7,20.2,6.9$, 4.9; IR (thin film, $\mathrm{NaCl}$ ) 3470, 3031, 2955, 2913, 2876 ,1728, 1496, 1456, 1414, 1391, 1368, 1252, 1206, 1135, 1006, 976, 899, 851, 741, $698 \mathrm{~cm}^{-1}$; HRMS (ESI) $515.3172 \mathrm{~m} / \mathrm{z}$ [calc $\mathrm{M}+\mathrm{Na}^{+}$ $\mathrm{C}_{28} \mathrm{H}_{48} \mathrm{NaO}_{5} \mathrm{Si}$ 515.3169].

${ }^{5}$ Ohtani, I.; Kusumi, T.; Kashman, Y.; Kakisawa, H. J. Am. Chem. Soc. 1991, 113, 4092. 


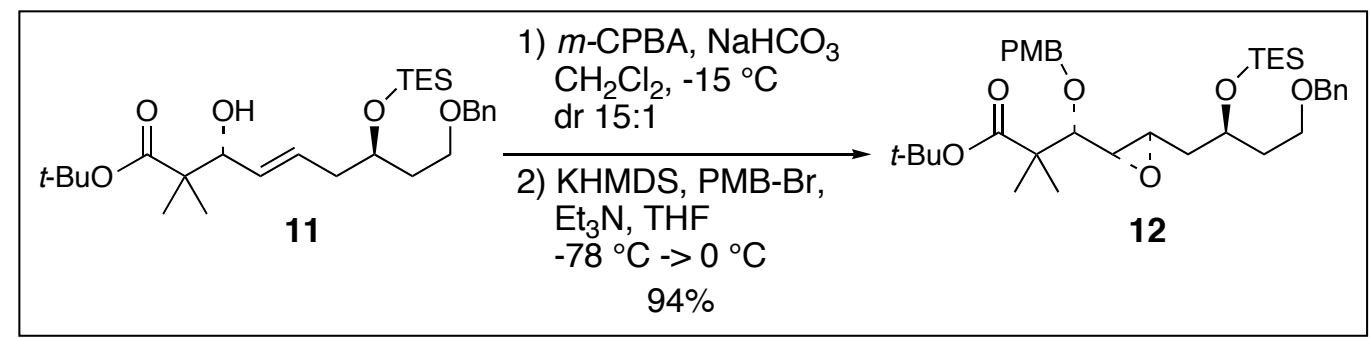

Epoxide 12: A solution of $11(679 \mathrm{mg}, 1.38 \mathrm{mmol})$ in $\mathrm{CH}_{2} \mathrm{Cl}_{2}(14 \mathrm{~mL})$ containing suspended solid $\mathrm{NaHCO}_{3}(350 \mathrm{mg}, 4.14 \mathrm{mmol})$ was cooled to $-78{ }^{\circ} \mathrm{C}$. Purified $\mathrm{m}$-CPBA (475 mg, $\left.2.76 \mathrm{mmol}\right)$ was added and the reaction flask was transferred to $\mathrm{a}-15^{\circ} \mathrm{C}$ cryocool bath. The mixture was stirred for $8.5 \mathrm{~h}$ at $-15{ }^{\circ} \mathrm{C}$, then was diluted with $\mathrm{Et}_{2} \mathrm{O}$ and $20 \% \mathrm{Na}_{2} \mathrm{~S}_{2} \mathrm{O}_{3}$ and stirred until the layers were clear. The organic layer was washed with $20 \% \mathrm{Na}_{2} \mathrm{~S}_{2} \mathrm{O}_{3}, 1 \mathrm{M} \mathrm{K}_{2} \mathrm{CO}_{3}$ and brine and then dried $\left(\mathrm{MgSO}_{4}\right)$ and filtered. Concentration of the filtrate under reduced pressure provided the desired epoxide (dr 15:1) as a clear oil, which was used in the next step without further purification.

To solution of the epoxide in THF $(14 \mathrm{~mL})$ was added $\mathrm{Et}_{3} \mathrm{~N}(580 \mu \mathrm{L}, 4.14 \mathrm{mmol})$ followed by $p$-methoxybenzyl bromide ${ }^{6}(350 \mu \mathrm{L}, 2.76 \mathrm{mmol})$. The mixture was cooled to $-78{ }^{\circ} \mathrm{C}$ and a solution of KHMDS (385 mg, $1.93 \mathrm{mmol})$ in THF (1 mL) was added dropwise. This mixture was stirred for 15 min, then was warmed to $0{ }^{\circ} \mathrm{C}$ and stirred for an additional $30 \mathrm{~min}$ before saturated $\mathrm{NaHCO}_{3}$ was added. This mixture was stirred for $1 \mathrm{~h}$ at room temperature to ensure complete hydrolysis of the $p$ methoxybenzyl bromide. After this time, the mixture was diluted with $\mathrm{Et}_{2} \mathrm{O}$ and the organic layer was washed with saturated $\mathrm{NaHCO}_{3}$ and brine and then dried $\left(\mathrm{MgSO}_{4}\right)$. Concentration of the filtered solution under reduced pressure and purification of the crude material via column chromatography $\left(\mathrm{SiO}_{2}, 19: 1 \rightarrow 11: 1\right.$ hexanes:EtOAc) yielded 12 as a clear oil $(159 \mathrm{mg}, 94 \%$, dr 15:1). This mixture was used without separation in the next step. Characterization data are reported for the major diastereomer only: $[\square]_{\mathrm{D}}{ }^{27.0}+14.7$ (c 1.34, $\left.\mathrm{CH}_{2} \mathrm{Cl}_{2}\right) ;{ }^{1} \mathrm{H}$ NMR (500 MHz, $\left.\mathrm{CDCl}_{3}\right) \square 7.35-7.27$ (m, $\left.7 \mathrm{H}\right), 6.85(\mathrm{~m}, 2 \mathrm{H})$, $4.83(\mathrm{~d}, \mathrm{~J}=11.0 \mathrm{~Hz}, 1 \mathrm{H}), 4.50(\mathrm{~m}, 3 \mathrm{H}), 4.10$ (p, J = $7.0 \mathrm{~Hz}, 1 \mathrm{H}), 3.88(\mathrm{~s}, 3 \mathrm{H}), 3.55(\mathrm{~m}, 2 \mathrm{H}), 3.22(\mathrm{~d}, \mathrm{~J}$ $=7.5 \mathrm{~Hz}, 1 \mathrm{H}), 2.90(\mathrm{~m}, 2 \mathrm{H}), 1.96-1.79(\mathrm{~m}, 3 \mathrm{H}), 1.44-1.37(\mathrm{~m}, 1 \mathrm{H}), 1.42(\mathrm{~s}, 9 \mathrm{H}), 1.21(\mathrm{~s}, 3 \mathrm{H}), 1.15(\mathrm{~s}$, $3 \mathrm{H}), 0.98(\mathrm{t}, \mathrm{J}=8.0 \mathrm{~Hz}, 9 \mathrm{H}), 0.64$ (q, J = 8.0 Hz, 6H); ${ }^{13} \mathrm{C} \mathrm{NMR}\left(125 \mathrm{MHz}, \mathrm{CDCl}_{3}\right) \square 175.0,158.8$, $138.4,130.8,129.1,128.3,127.6,127.5,113.4,84.3,80.3,72.9,72.2,67.6,66.5,58.8,55.1,52.3$, 47.2, 40.0, 37.9, 27.9, 22.4, 21.0, 6.9, 4.9; IR (thin film, NaCl) 2953, 2876, 1731, 1614, 1587, 1514, 1496, 1456, 1416, 1391, 1367, 1301, 1248, 1172, 1143, 1114, 1040, 1011, 892, 850, 820, 742, 698, $674 \mathrm{~cm}^{-1}$; HRMS (ESI) $651.3697 \mathrm{~m} / \mathrm{z}$ [calc M + Na ${ }^{+} \mathrm{C}_{36} \mathrm{H}_{56} \mathrm{NaO}_{7} \mathrm{Si} 651.3693$ ].

${ }^{6}$ Duke, S. S.; Boots, M. R. J. Med. Chem. 1983, 26, 1556. 


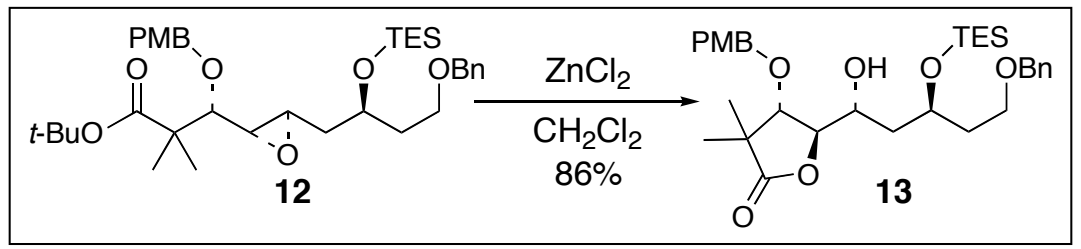

Lactone 13: Epoxide $12(797 \mathrm{mg}, 1.27 \mathrm{mmol})$ was dissolved in $\mathrm{Et}_{2} \mathrm{O}$ and anhydrous $\mathrm{ZnCl}_{2}$ (610 mg, $4.45 \mathrm{mmol}$ ) added. The reaction was stirred overnight at ambient temperature quenched by the addition of saturated $\mathrm{NaHCO}_{3}$ and the resulting was mixture stirred until gas evolution ceased. The organic layer was washed with saturated $\mathrm{NaHCO}_{3}$ and brine and then dried $\left(\mathrm{MgSO}_{4}\right)$. Concentration of the filtered solution under reduced pressure and purification of the resulting material via column chromatography $\left(\mathrm{SiO}_{2}, 5: 1\right.$ hexanes:EtOAc) provided 13 as a single diastereomer (625 $\left.\mathrm{mg}, 86 \%\right)$ : $[\square]_{\mathrm{D}}{ }^{27.0}+25.9\left(\mathrm{c} 0.80, \mathrm{CH}_{2} \mathrm{Cl}_{2}\right) ;{ }^{1} \mathrm{H}$ NMR $\left(500 \mathrm{MHz}, \mathrm{CDCl}_{3}\right) \square$ 7.37-7.24 (m, 7H), 6.89 (m, 2H), 4.54 (A of $\mathrm{AB}$ quartet, $\mathrm{J}=11.0 \mathrm{~Hz}, 1 \mathrm{H}$ ), 4.51 (A of $\mathrm{AB}$ quartet, $\mathrm{J}=12.5 \mathrm{~Hz}, 1 \mathrm{H}$ ), 4.49 (B of AB quartet, $\mathrm{J}$ $=12.0 \mathrm{~Hz}, 1 \mathrm{H}), 4.46(\mathrm{~B}$ of $\mathrm{AB}$ quartet, $\mathrm{J}=12.0 \mathrm{~Hz}, 1 \mathrm{H}), 4.24(\mathrm{p}, \mathrm{J}=6.0 \mathrm{~Hz}, 1 \mathrm{H}), 4.16(\mathrm{~m}, 1 \mathrm{H}), 4.07$ (dd, J = 6.5, $4.5 \mathrm{~Hz}, 1 \mathrm{H}), 4.02(\mathrm{~d}, \mathrm{~J}=6.5 \mathrm{~Hz}, 1 \mathrm{H}), 3.81(\mathrm{~s}, 3 \mathrm{H}), 3.51(\mathrm{~m}, 2 \mathrm{H}), 3.45$ (d, J = 2.5 Hz, 1H), $1.94(\mathrm{dq}, \mathrm{J}=14.0,6.0 \mathrm{~Hz}, 1 \mathrm{H}), 1.85(\mathrm{dq}, \mathrm{J}=13.5,7.0 \mathrm{~Hz}, 1 \mathrm{H}), 1.72\left(\mathrm{~A}\right.$ of $\mathrm{ABX}, \mathrm{J}_{\mathrm{AB}}=15.0 \mathrm{~Hz}, \mathrm{~J}_{\mathrm{AX}}=$ $4.5 \mathrm{~Hz}, 1 \mathrm{H}), 1.67\left(\mathrm{~B}\right.$ of $\left.\mathrm{ABX}, \mathrm{J}_{\mathrm{AB}}=10.5 \mathrm{~Hz}, \mathrm{~J}_{\mathrm{BX}}=5.0 \mathrm{~Hz}, 1 \mathrm{H}\right), 1.30(\mathrm{~s}, 3 \mathrm{H}), 1.26(\mathrm{~s}, 3 \mathrm{H}), 0.97(\mathrm{t}, \mathrm{J}=$ $8.0 \mathrm{~Hz}, 9 \mathrm{H}), 0.63$ (q, J = 7.5 Hz, 6H); $\left.{ }^{13} \mathrm{C} \mathrm{NMR} \mathrm{(125} \mathrm{MHz,} \mathrm{CDCl}_{3}\right) \square 180.2,159.4,138.2,129.6$, $129.5,128.4,127.7,127.6,113.8,83.6,81.8,73.0,72.4,68.2,67.7,66.5,55.5,43.7,37.7,36.6,24.7$, 19.4, 6.8, 4.8; IR (thin film, NaCl) 3458, 2954, 2876, 1779, 1612, 1586, 1515, 1496, 1462, 1414, 1388, 1366, 1302, 1249, 1211, 1174, 1103, 1037, 912, 881, 822, 739, $699 \mathrm{~cm}^{-1}$; HRMS (ESI) $595.3079 \mathrm{~m} / \mathrm{z}$ [calc $\mathrm{M}+\mathrm{Na}^{+} \mathrm{C}_{32} \mathrm{H}_{48} \mathrm{NaO}_{7} \mathrm{Si}$ 595.3067].

Conformation of the C(7)-C(5) stereochemistry of 13 by the Rychnovsky method: ${ }^{7}$ The TES ether was cleaved by treatment of a small portion of 13 with PPTS in $\mathrm{CH}_{2} \mathrm{Cl}_{2} / \mathrm{MeOH}$. 2,2Dimethoxypropane was then added and the solvent was removed under reduced pressure. More 2,2dimethoxypropane and $\mathrm{CH}_{2} \mathrm{Cl}_{2}$ were added and the solution concentrated for a second time. The crude reaction mixture was passed through a plug of silica gel eluting with 3:1 hexanes:EtOAc and then concentrated under reduced pressure to afforded the 1,3 -acetonide having ${ }^{13} \mathrm{C} \mathrm{NMR}$ data that are consistent with 1,3-anti stereochemistry at C(5)-C(7):

\footnotetext{
${ }^{7}$ Rychnovsky, S.; Rogers, B.; Richardson, T. Acc. Chem. Res. 1998, 31, 9. 

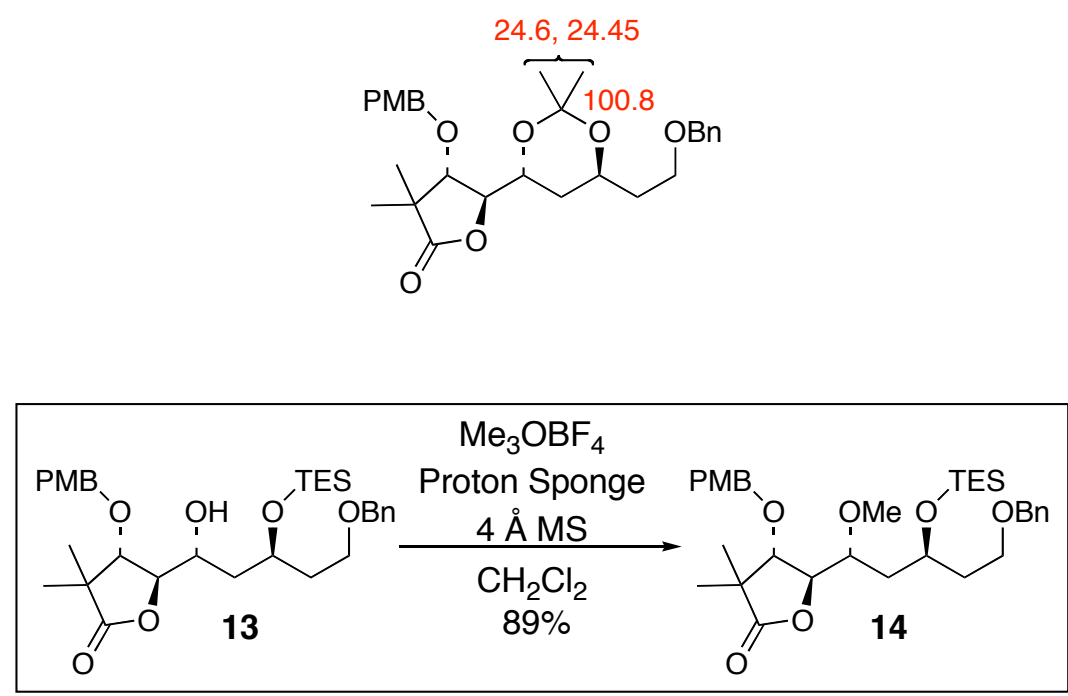

Methyl ether 14: To a solution of alcohol $13(592 \mathrm{mg}, 1.03 \mathrm{mmol})$ in $\mathrm{CH}_{2} \mathrm{Cl}_{2}(10 \mathrm{~mL})$ was added $4 \AA$ molecular sieves (freshly activated under vacuum, $200 \mathrm{mg}$ ), Proton Sponge (1.3 g, 7.5 $\mathrm{mmol})$ and $\mathrm{Me}_{3} \mathrm{OBF}_{4}(610 \mathrm{mg}, 4.12 \mathrm{mmol})$. The suspension was stirred at ambient temperature for $5 \mathrm{~h}$, diluted with EtOAc and filtered. The organic layer was washed with water, $1 \mathrm{M} \mathrm{NaHSO}_{4}$, saturated $\mathrm{NaHCO}_{3}$ and brine and then dried $\left(\mathrm{MgSO}_{4}\right)$. Concentration of the filtered solution under reduced pressure and purification of the crude product via column chromatography $\left(\mathrm{SiO}_{2}, 7: 1\right.$ hexanes:EtOAc) yielded 14 was as a clear oil $(537 \mathrm{mg}, 89 \%)$ : [ $]_{\mathrm{D}}{ }^{27.0}+44.1$ (c $\left.1.03, \mathrm{CH}_{2} \mathrm{Cl}_{2}\right)$; ${ }^{1} \mathrm{H} \mathrm{NMR}(500 \mathrm{MHz}$, $\left.\mathrm{CDCl}_{3}\right) \square 7.37-7.28(\mathrm{~m}, 5 \mathrm{H}), 7.23(\mathrm{~m}, 2 \mathrm{H}), 6.89(\mathrm{~m}, 2 \mathrm{H}), 4.53$ (A of AB quartet, J = 10.5 Hz, 1H), 4.51 (A of $\mathrm{AB}$ quartet, $\mathrm{J}=12.0 \mathrm{~Hz}, 1 \mathrm{H}), 4.46$ (B of $\mathrm{AB}$ quartet, $\mathrm{J}=11.5 \mathrm{~Hz}, 1 \mathrm{H}$ ), 4.44 (B of $\mathrm{AB}$ quartet, $\mathrm{J}=$ $10.5 \mathrm{~Hz}, 1 \mathrm{H}), 4.26$ (dd, J = 7.5, $2.0 \mathrm{~Hz}, 1 \mathrm{H}), 4.08(\mathrm{~m}, 1 \mathrm{H}), 4.03$ (d, J = 7.0 Hz, 1H), 3.80 (app septet, J $=2.0 \mathrm{~Hz}, 1 \mathrm{H}), 3.80(\mathrm{~s}, 3 \mathrm{H}), 3.51(\mathrm{~m}, 2 \mathrm{H}), 3.46(\mathrm{~s}, 3 \mathrm{H}), 1.94(\mathrm{dtd}, \mathrm{J}=13.5,6.5,4.5 \mathrm{~Hz}, 1 \mathrm{H}), 1.79(\mathrm{dt}, \mathrm{J}$ $=13.5,7.0 \mathrm{~Hz}, 1 \mathrm{H}), 1.61(\mathrm{ddd}, \mathrm{J}=14.5,9.5,3.0 \mathrm{~Hz}, 1 \mathrm{H}), 1.50(\mathrm{ddd}, \mathrm{J}=14.5,9.5,3.0 \mathrm{~Hz}, 1 \mathrm{H}), 1.33(\mathrm{~s}$, $3 \mathrm{H}), 1.27(\mathrm{~s}, 3 \mathrm{H}), 0.98(\mathrm{t}, \mathrm{J}=7.5 \mathrm{~Hz}, 9 \mathrm{H}), 0.64$ (q, J = $7.5 \mathrm{~Hz}, 6 \mathrm{H}) ;{ }^{13} \mathrm{C} \mathrm{NMR}\left(125 \mathrm{MHz}, \mathrm{CDCl}_{3}\right) \square$ $180.0,159.4,138.4,129.5,129.4,128.3,127.5,127.5,113.8,83.0,81.7,76.6,73.0,72.7,67.0,66.6$, 59.2, 55.2, 43.7, 38.3, 38.2, 24.4, 19.4, 6.6, 5.2; IR (thin film, NaCl) 3031, 2954, 2876, 1781, 1613, 1586, 1515, 1496, 1414, 1388, 1366, 1302, 1210, 1174, 1115, 1037, 849, 822, 741, $698 \mathrm{~cm}^{-1}$; HRMS (ESI) $609.3235 \mathrm{~m} / \mathrm{z}$ [calc $\left.\mathrm{M}+\mathrm{Na}^{+} \mathrm{C}_{33} \mathrm{H}_{50} \mathrm{NaO}_{7} \mathrm{Si} 609.3224\right]$. 


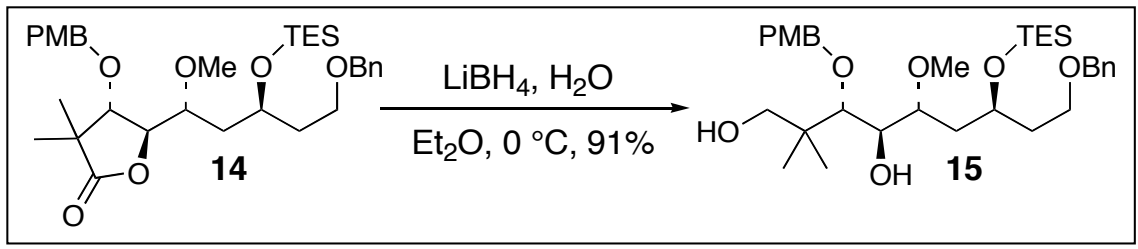

Diol 15: To a $0{ }^{\circ} \mathrm{C}$ mixture of lactone 14 (468 $\left.\mathrm{mg}, 0.798 \mathrm{mmol}\right)$ and water $(58 \mu \mathrm{L}, 3.2 \mathrm{mmol})$ in $\mathrm{Et}_{2} \mathrm{O}(8 \mathrm{~mL})$ was added $\mathrm{LiBH}_{4}(1.6 \mathrm{~mL}, 2 \mathrm{M}$ in THF, $3.2 \mathrm{mmol})$ dropwise. The solution was stirred at $0{ }^{\circ} \mathrm{C}$ for $2 \mathrm{~h}$, diluted with $\mathrm{Et}_{2} \mathrm{O}$ and saturated $\mathrm{NH}_{4} \mathrm{Cl}$ and the two-phase mixture was stirred until both layers were clear. The organic layer was washed with saturated $\mathrm{NaHCO}_{3}$ and brine, dried $\left(\mathrm{MgSO}_{4}\right)$, filtered and concentrated under reduced pressure. Purification via of the crude material via column

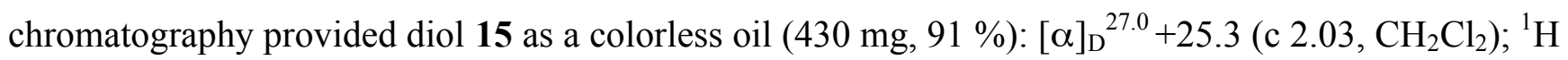
$\operatorname{NMR}\left(500 \mathrm{MHz}, \mathrm{CDCl}_{3}\right) \square 7.36-7.25(\mathrm{~m}, 7 \mathrm{H}), 6.87(\mathrm{~m}, 2 \mathrm{H}), 4.74(\mathrm{~d}, \mathrm{~J}=11.0 \mathrm{~Hz}, 1 \mathrm{H}), 4.53(\mathrm{~A}$ of AB quartet, $\mathrm{J}=12.0 \mathrm{~Hz}, 1 \mathrm{H}), 4.49(\mathrm{~B}$ of $\mathrm{AB}$ quartet, $\mathrm{J}=12.0 \mathrm{~Hz}, 1 \mathrm{H}), 4.41(\mathrm{~d}, \mathrm{~J}=11.0 \mathrm{~Hz}, 1 \mathrm{H}), 4.16(\mathrm{~m}$, $1 \mathrm{H}), 4.13$ (dd, J = 8.5, 3.0 Hz, 1H), 2.26 (br s, 1H), 3.81 (s, 3H), 3.77 (ddd, J = 7.5, 5.0, 3.0 Hz, 1H), $3.57(\mathrm{~m}, 3 \mathrm{H}), 3.42$ (s, 1H), 3.40 (s $3 \mathrm{H}), 3.27$ (d, J = 8.5 Hz, 1H), 1.93 (dtd, J = 13.5, 7.0, 4.0 Hz, 1H), $1.86(\mathrm{dt}, \mathrm{J}=13.5,7.0 \mathrm{~Hz}, 1 \mathrm{H}), 1.77(\mathrm{~m}, 2 \mathrm{H}), 1.07(\mathrm{~s}, 3 \mathrm{H}), 1.01(\mathrm{~s}, 3 \mathrm{H}), 0.91(\mathrm{t}, \mathrm{J}=8.0 \mathrm{~Hz}, 9 \mathrm{H}), 0.57$ $(\mathrm{qd}, \mathrm{J}=7.5,2.0 \mathrm{~Hz}, 6 \mathrm{H}) ;{ }^{13} \mathrm{C} \operatorname{NMR}\left(125 \mathrm{MHz}, \mathrm{CDCl}_{3}\right) \square$ 159.0, 138.5, 130.7, 128.6, 128.3, 127.6, 127.5, 113.6, 84.2, 78.6, 74.5, 73.0, 70.5, 70.1, 67.1, 66.7, 56.9, 55.2, 41.2, 38.3, 36.1, 23.8, 20.3, 7.0, 5.2; IR (thin film, NaCl) 3411, 2955, 2876, 1613, 1586, 1515, 1456, 1388, 1302, 1248, 1174, 1097 , 1051, 821, 741, $698 \mathrm{~cm}^{-1}$; HRMS (ESI) $613.3533 \mathrm{~m} / \mathrm{z}$ [calc $\mathrm{M}+\mathrm{Na}^{+} \mathrm{C}_{33} \mathrm{H}_{54} \mathrm{NaO}_{7} \mathrm{Si}$ 613.3537].

The absolute configuration of the $\mathrm{C}(8)$-hydroxyl group for compound $\mathbf{1 5}$ was determined by ${ }^{1} \mathrm{H}$ NMR analysis of the bis-Mosher ester:

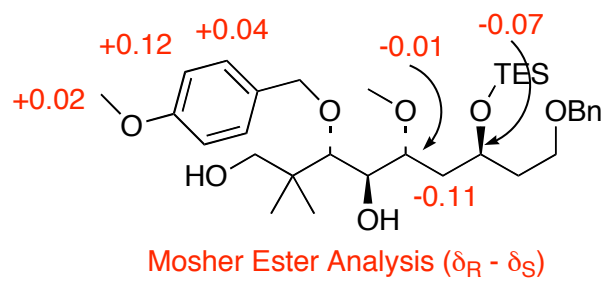




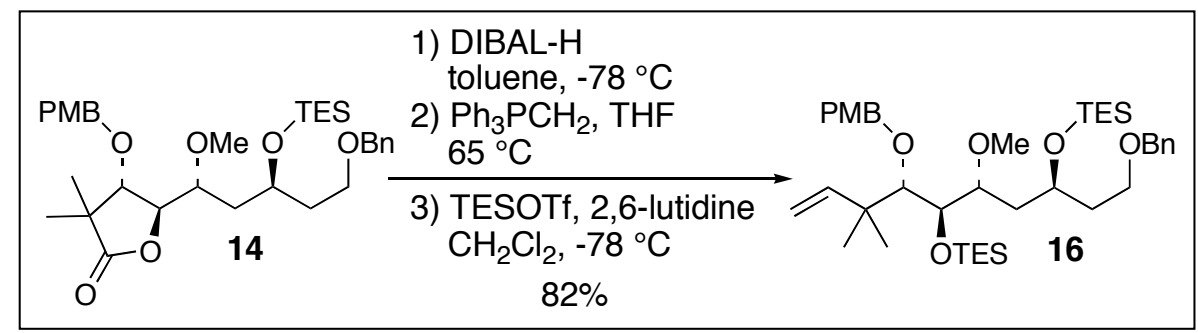

Alkene 16: To a $-78^{\circ} \mathrm{C}$ solution of lactone $14(496 \mathrm{mg}, 0.850 \mathrm{mmol})$ in toluene $(8.5 \mathrm{~mL})$ was added DIBAL-H (740 $\mu \mathrm{L}, 1.5 \mathrm{M}$ in hexanes, $1.11 \mathrm{mmol}))$ slowly down side of flask. The resulting mixture was stirred for $30 \mathrm{~min}$ at $-78^{\circ} \mathrm{C}$. Saturated Rochelle's salt and $\mathrm{Et}_{2} \mathrm{O}$ were then added and the two-phase mixture was allowed to stir at room temperature until the layers were clear. The organic layer was washed with brine and dried $\left(\mathrm{MgSO}_{4}\right)$. Concentration of the filtered solution under reduced pressure and purification of the resulting material via column chromatography $\left(\mathrm{SiO}_{2}, 3: 1\right.$ hexanes:EtOAc) provided the lactol (453 mg) as a 2:1 mixture of anomers.

Methyltriphenylphosphonium bromide $\left(790 \mathrm{mg}, 2.21 \mathrm{mmol}\right.$, dried at $120{ }^{\circ} \mathrm{C}$ under vacuum and stored in a glove box) was suspended in THF $(2 \mathrm{~mL})$, and the suspension was cooled to $0{ }^{\circ} \mathrm{C} . n$-BuLi $(870 \mu \mathrm{L}, 2.5 \mathrm{M}$ in hexanes, $2.3 \mathrm{mmol})$ ) was added dropwise and the reaction mixture was warmed to room temperature and stirred for $1 \mathrm{~h}$ during which time a yellow/orange color developed. This ylide solution was then added to a solution of the lactol isolated above (327 mg, $0.555 \mathrm{mmol})$ in THF (5 mL) via a teflon cannula. The yellow suspension was heated to $65{ }^{\circ} \mathrm{C}$ for $16.5 \mathrm{~h}$, cooled to room temperature and quenched with saturated $\mathrm{NH}_{4} \mathrm{Cl}$. After dilution of the mixture with $\mathrm{Et}_{2} \mathrm{O}$, the organic layer was washed with saturated $\mathrm{NaHCO}_{3}$ and brine and then dried $\left(\mathrm{MgSO}_{4}\right)$, filtered, and concentrated. Purification of the crude mixture via column chromatography $\left(\mathrm{SiO}_{2}, 5: 1\right.$ hexanes:EtOAc) yielded the terminal olefin as a clear oil which was used directly in the next reaction.

The olefin isolated above was dissolved in $\mathrm{CH}_{2} \mathrm{Cl}_{2}(6 \mathrm{~mL})$, and 2,6-lutidine $(260 \mu \mathrm{L}, 2.24$ mmol) was added. The solution was cooled to $-78^{\circ} \mathrm{C}$ and triethylsilyltrifluoromethane sulfonate (320 $\mu \mathrm{L}, 1.42 \mathrm{mmol}$ ) was added dropwise. This mixture was stirred for $45 \mathrm{~min}$, then the reaction was quenched with saturated $\mathrm{NaHCO}_{3}$ and diluted with $\mathrm{Et}_{2} \mathrm{O}$. The organic layer was washed with saturated $\mathrm{NaHCO}_{3}$ and brine and dried $\left(\mathrm{MgSO}_{4}\right)$. Concentration of the filtered solution under reduced pressure and purification of the resulting oil via column chromatography $\left(\mathrm{SiO}_{2}, 19: 1\right.$ hexanes:EtOAc) provided 16 as a colorless oil (354 mg, 82\% three steps): $[\square]_{\mathrm{D}}{ }^{27.0}+13.1\left(\mathrm{c} 0.49, \mathrm{CH}_{2} \mathrm{Cl}_{2}\right) ;{ }^{1} \mathrm{H} \mathrm{NMR}(500 \mathrm{MHz}$, $\left.\mathrm{CDCl}_{3}\right) \square 7.35-7.26(\mathrm{~m}, 7 \mathrm{H}), 6.86(\mathrm{~m}, 2 \mathrm{H}), 6.06(\mathrm{dd}, \mathrm{J}=17.5,11.0 \mathrm{~Hz}, 1 \mathrm{H}), 5.02(\mathrm{dd}, \mathrm{J}=17.5,1.5 \mathrm{~Hz}$, 1H), $5.00(\mathrm{dd}, \mathrm{J}=11.0,1.5 \mathrm{~Hz}, 1 \mathrm{H}), 4.86(\mathrm{~d}, \mathrm{~J}=11.0 \mathrm{~Hz}, 1 \mathrm{H}), 4.43(\mathrm{~d}, \mathrm{~J}=11.5 \mathrm{~Hz}, 1 \mathrm{H}), 4.41(\mathrm{~s}, 2 \mathrm{H})$, $4.12(\mathrm{~d}, \mathrm{~J}=3.5 \mathrm{~Hz}, 1 \mathrm{H}), 4.06(\mathrm{~m}, 1 \mathrm{H}), 3.80(\mathrm{~s}, 3 \mathrm{H}), 3.63(\mathrm{~d}, \mathrm{~J}=10.0 \mathrm{~Hz}, 1 \mathrm{H}), 3.47$ (dt, J = 9.0, 7.5 Hz, 
1H), $3.42(\mathrm{dt}, \mathrm{J}=9.5,7.5 \mathrm{~Hz}, 1 \mathrm{H}), 3.28(\mathrm{~s}, 3 \mathrm{H}), 3.24(\mathrm{~d}, \mathrm{~J}=3.5 \mathrm{~Hz}, 1 \mathrm{H}), 1.81(\mathrm{~m}, 3 \mathrm{H}), 1.68(\mathrm{ddd}, \mathrm{J}=$ 14.0, 10.0, 3.0 Hz, 1H), 1.12 (s, 3H), 1.11 (s, 3H), 0.98 (t, J = 8.0 Hz, 9H), 0.94 (t, J = 8.0 Hz, 9H), $0.64(\mathrm{q}, \mathrm{J}=8.0 \mathrm{~Hz}, 6 \mathrm{H}), 0.57$ (q, J = 8.0 Hz, 6H); ${ }^{13} \mathrm{C} \mathrm{NMR}\left(125 \mathrm{MHz}, \mathrm{CDCl}_{3}\right) \square 158.7,145.8,138.7$, $131.5,128.7,128.2,127.5,127.3,113.4,111.3,90.2,79.0,75.1,73.4,72.9,67.2,67.0,56.7,55.2$, 41.7, 38.4, 37.5, 25.3, 24.5, 7.1, 5.3, 5.1; IR (thin film, NaCl) 2954, 2876, 1614, 1587, 1514, 1462, $1515,1358,1301,1248,1173,1099,1063,1009,976,912,822,739,697,672 \mathrm{~cm}^{-1}$; HRMS (ESI) $723.4487 \mathrm{~m} / \mathrm{z}$ [calc M+ $\mathrm{Na}^{+} \mathrm{C}_{40} \mathrm{H}_{68} \mathrm{NaO}_{6} \mathrm{Si}_{2} 723.4452$ ].

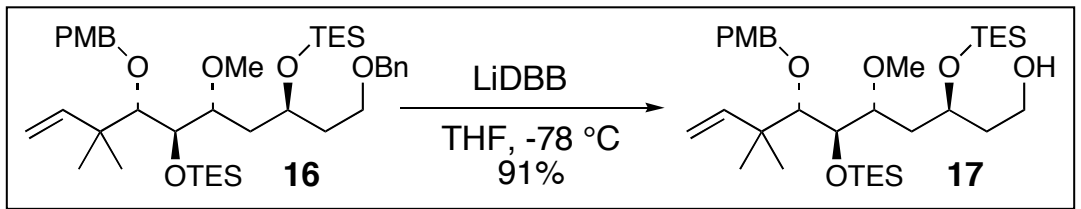

Alcohol 17: 4,4'-Di-tert-butylbiphenyl (635 mg, $2.94 \mathrm{mmol}$ ) was dissolved in THF (6 mL) and the reaction vessel was flushed with argon. Lithium wire (ca 15-20 mg) was cut into small pieces, washed with hexanes, methanol and ether and then added to the above solution under a stream of argon. The reaction mixture was placed in a $0^{\circ} \mathrm{C}$ sonicator bath and sonicated for $3 \mathrm{~h}$ to provide a deep blue/green solution. A solution of benzyl ether $16(321 \mathrm{mg}, 0.458 \mathrm{mmol})$ in THF $(4.5 \mathrm{~mL})$ under argon was cooled to $-78{ }^{\circ} \mathrm{C}$ and the LiDBB solution was added dropwise to maintain a persistent deep blue/green color. After $2 \mathrm{~h}$ the reaction was judged complete by TLC analysis and was then quenched with saturated $\mathrm{NH}_{4} \mathrm{Cl}$. This mixture was diluted with $\mathrm{Et}_{2} \mathrm{O}$ and the organic layer was washed with saturated $\mathrm{NaHCO}_{3}$ and brine and dried $\left(\mathrm{MgSO}_{4}\right)$. Concentration of the filtered solution under reduced pressure and purification of the mixture via column chromatography $\left(\mathrm{SiO}_{2}, 11: 1 \rightarrow 7: 1\right.$ hexanes:EtOAc) provided alcohol 17 as a clear oil $(256 \mathrm{mg}, 91 \%)$ : [ []$_{\mathrm{D}}{ }^{27.0}+8.0\left(\mathrm{c} 0.69, \mathrm{CH}_{2} \mathrm{Cl}_{2}\right) ;{ }^{1} \mathrm{H}$ $\operatorname{NMR}\left(500 \mathrm{MHz}, \mathrm{CDCl}_{3}\right) \square 7.30(\mathrm{~m}, 2 \mathrm{H}), 6.87(\mathrm{~m}, 2 \mathrm{H}), 6.07(\mathrm{dd}, \mathrm{J}=17.5,10.5 \mathrm{~Hz}, 1 \mathrm{H}), 5.02(\mathrm{~m}, 2 \mathrm{H})$, $4.87(\mathrm{~d}, \mathrm{~J}=11.0 \mathrm{~Hz}, 1 \mathrm{H}), 4.47(\mathrm{~d}, \mathrm{~J}=11.0 \mathrm{~Hz}, 1 \mathrm{H}), 4.13(\mathrm{~d}, \mathrm{~J}=2.0 \mathrm{~Hz}, 1 \mathrm{H}), 4.10(\mathrm{~m}, 1 \mathrm{H}), 3.81(\mathrm{~s}$, $3 \mathrm{H}), 3.78(\mathrm{~m}, 1 \mathrm{H}), 3.65(\mathrm{~m}, 1 \mathrm{H}), 3.58(\mathrm{br} \mathrm{d}, \mathrm{J}=9.0 \mathrm{~Hz}, 1 \mathrm{H}), 3.28(\mathrm{~d}, \mathrm{~J}=3.0 \mathrm{~Hz}, 1 \mathrm{H}), 3.27(\mathrm{~s}, 3 \mathrm{H})$, 2.48 (br s, 1H), 1.97 (ddd, J = 15.0, 8.0, $2.0 \mathrm{~Hz}, 1 \mathrm{H}), 1.81(\mathrm{~m}, 2 \mathrm{H}), 1.67(\mathrm{~m}, 1 \mathrm{H}), 1.12(\mathrm{~s}, 3 \mathrm{H}), 1.11$ (s, $3 \mathrm{H}), 1.00(\mathrm{t}, \mathrm{J}=8.0 \mathrm{~Hz}, 9 \mathrm{H}), 0.94(\mathrm{t}, \mathrm{J}=8.0 \mathrm{~Hz}, 9 \mathrm{H}), 0.66(\mathrm{q}, \mathrm{J}=8.0 \mathrm{~Hz}, 6 \mathrm{H}), 0.58(\mathrm{qd}, \mathrm{J}=8.0,3.5$ $\mathrm{Hz}, 6 \mathrm{H}) ;{ }^{13} \mathrm{C}$ NMR $\left(125 \mathrm{MHz}, \mathrm{CDCl}_{3}\right) \square 158.8,145.6,131.3,128.8,113.5,111.4,90.4,79.4,75.5$, $73.1,69.4,59.8,56.5,55.2,41.6,39.5,36.8,25.2,24.9,7.0,6.9,5.1,5.1$; IR (thin film, $\mathrm{NaCl}$ ) 3442 , 3081, 2954, 2877, 161, 1587, 1515, 1464, 1516, 1378, 1302, 1173, 1096, 1063, 1010, 975, 913, 823, $742,671 \mathrm{~cm}^{-1}$; HRMS (ESI) $633.3991 \mathrm{~m} / \mathrm{z}$ [calc M $+\mathrm{Na}^{+} \mathrm{C}_{33} \mathrm{H}_{62} \mathrm{NaO}_{6} \mathrm{Si}_{2} 633.3983$ ]. 


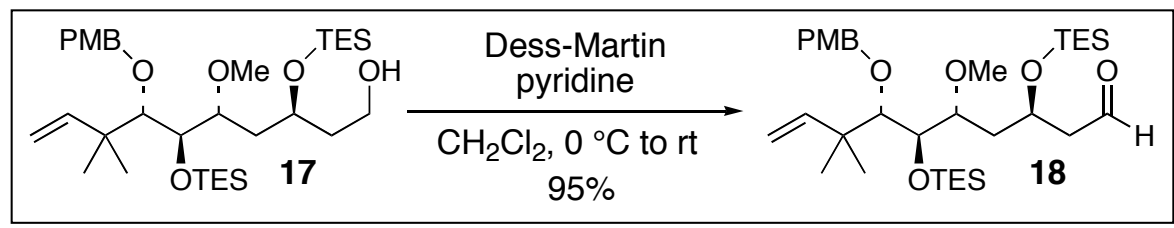

Aldehyde 18: Alcohol $17(67 \mathrm{mg}, 0.11 \mathrm{mmol})$ was dissolved in undistilled $\mathrm{CH}_{2} \mathrm{Cl}_{2}$ and pyridine $(35 \mu \mathrm{L}, 0.44 \mathrm{mmol})$ was added to the solution. The solution was cooled to $0{ }^{\circ} \mathrm{C}$, then DessMartin periodinane (65 mg, $0.15 \mathrm{mmol}$ ) was added and the suspension was stirred for $1 \mathrm{~h} \mathrm{at} 0{ }^{\circ} \mathrm{C}$ and for $30 \mathrm{~min}$ at room temperature. The reaction was quenched by the addition of $20 \% \mathrm{Na}_{2} \mathrm{~S}_{2} \mathrm{O}_{3}$ and resulting two-phase mixture was stirred till both layers were clear. The mixture was diluted with additional $\mathrm{E}_{2} \mathrm{O}$, the organic layer was separated and washed with $20 \% \mathrm{Na}_{2} \mathrm{~S}_{2} \mathrm{O}_{3}$, saturated $\mathrm{NaHCO}_{3}$ and brine and then dried $\left(\mathrm{MgSO}_{4}\right)$. Concentration of the filtered solution under reduced pressure and purification of the resulting oil via column chromatography $\left(\mathrm{SiO}_{2}, 24: 1\right.$ hexanes:EtOAc) yielded

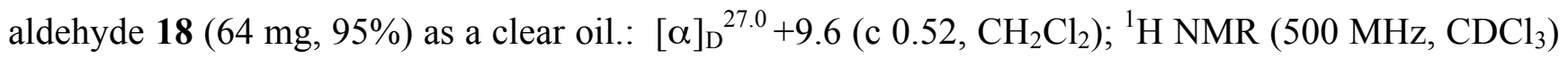
$\square 9.68(\mathrm{t}, \mathrm{J}=2.5 \mathrm{~Hz}, 1 \mathrm{H}), 7.28(\mathrm{~d}, \mathrm{~J}=8.5 \mathrm{~Hz}, 2 \mathrm{H}), 6.78(\mathrm{~d}, \mathrm{~J}=8.5 \mathrm{~Hz}, 2 \mathrm{H}), 6.06(\mathrm{~m}, 1 \mathrm{H}), 5.02(\mathrm{~m}$, 2H), $4.86(\mathrm{~d}, \mathrm{~J}=11.0 \mathrm{~Hz}, 1 \mathrm{H}), 4.46(\mathrm{~d}, \mathrm{~J}=11.0 \mathrm{~Hz}, 1 \mathrm{H}), 4.35(\mathrm{~m}, 1 \mathrm{H}), 4.13(\mathrm{~d}, \mathrm{~J}=2.5 \mathrm{~Hz}, 1 \mathrm{H}), 3.82$ $(\mathrm{s}, 3 \mathrm{H}), 3.62(\mathrm{~d}, \mathrm{~J}=10.0 \mathrm{~Hz}, 1 \mathrm{H}), 3.29(\mathrm{~d}, \mathrm{~J}=3.0 \mathrm{~Hz}, 1 \mathrm{H}), 3.25(\mathrm{~s}, 3 \mathrm{H}), 2.54\left(\mathrm{~A}\right.$ of $\mathrm{ABX}_{2}, \mathrm{~J}_{\mathrm{AB}}=16.0$ $\left.\mathrm{Hz}, \mathrm{J}_{\mathrm{AX}}=6.0,2.5 \mathrm{~Hz}, 1 \mathrm{H}\right), 2.45\left(\mathrm{~B}\right.$ of $\left.\mathrm{ABX}_{2}, \mathrm{~J}_{\mathrm{AB}}=16.0 \mathrm{~Hz}, \mathrm{~J}_{\mathrm{BX}}=4.5,2.5 \mathrm{~Hz}, 1 \mathrm{H}\right), 2.05(\mathrm{ddd}, \mathrm{J}=$ 15.0, 8.0, $2.0 \mathrm{~Hz}, 1 \mathrm{H}), 1.80(\mathrm{ddd}, \mathrm{J}=15.0,10.5,5.0 \mathrm{~Hz}, 1 \mathrm{H}), 1.28(\mathrm{~s}, 3 \mathrm{H}), 1.11(\mathrm{~s}, 3 \mathrm{H}), 0.99(\mathrm{t}, \mathrm{J}=8.0$ $\mathrm{Hz}, 9 \mathrm{H}), 0.92(\mathrm{t}, \mathrm{J}=8.0 \mathrm{~Hz}, 9 \mathrm{H}), 0.64(\mathrm{q}, \mathrm{J}=8.0 \mathrm{~Hz}, 6 \mathrm{H}), 0.56(\mathrm{q}, \mathrm{J}=8.0 \mathrm{~Hz}, 6 \mathrm{H}) ;{ }^{13} \mathrm{C} \mathrm{NMR}(125$ $\left.\mathrm{MHz}, \mathrm{CDCl}_{3}\right) \square 202.6,158.9,145.5,131.2,128.8,113.5,111.5,90.5,78.9,75.6,72.8,66.1,56.4,55.2$, 52.1, 41.5, 38.2, 25.2, 25.0, 7.0, 6.9, 5.1, 5.0; IR (thin film, NaCl) 1956, 2877, 2730, 1726, 1614, 1587, 1515, 1464, 1516, 1378, 1302, 1249, 1173, 1096, 1009, 976, 913, 823, 743, $671 \mathrm{~cm}^{-1}$; HRMS (ESI) $631.3835 \mathrm{~m} / \mathrm{z}$ [calc $\mathrm{M}+\mathrm{Na}^{+} \mathrm{C}_{33} \mathrm{H}_{60} \mathrm{NaO}_{6} \mathrm{Si}_{2}$ 631.3826].

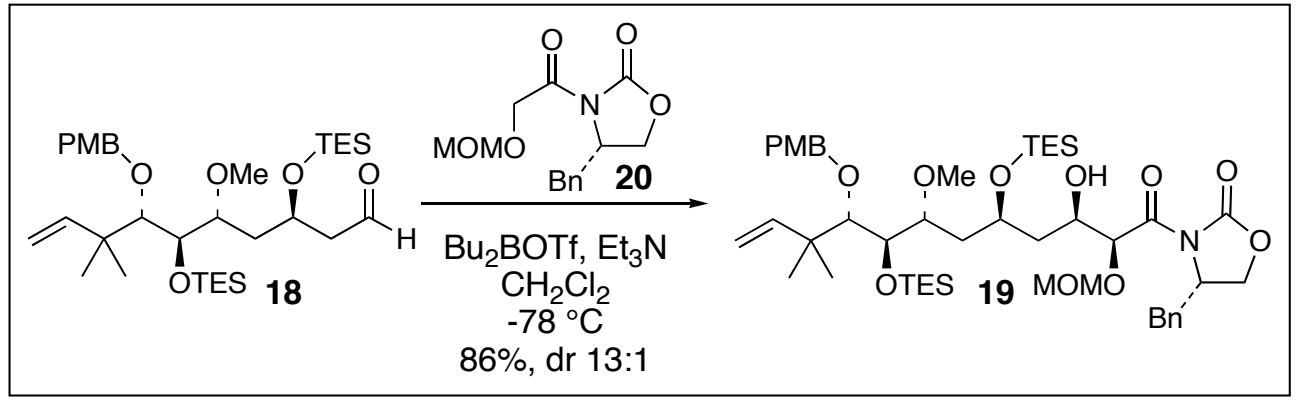

Aldol Product 19: Oxazolidinone 20 (39 mg, $0.14 \mathrm{mmol})$ was dissolved in $\mathrm{CH}_{2} \mathrm{Cl}_{2}(350 \mu \mathrm{L})$ and $\mathrm{Et}_{3} \mathrm{~N}(26 \mu \mathrm{L}, 0.18 \mathrm{mmol})$ was added to the solution. The temperature of the reaction mixture was held to between -20 and $-30{ }^{\circ} \mathrm{C}$ while neat dibutylboron triflate $(40 \mu \mathrm{L}, 0.16 \mathrm{mmol})$ was added 
dropwise. After the addition was complete, the solution was cooled to $-78{ }^{\circ} \mathrm{C}$, stirred for $3 \mathrm{~h}$ and then warmed to $0{ }^{\circ} \mathrm{C}$ for $30 \mathrm{~min}$ to ensure complete enolization. The enolate solution was re-cooled to -78 ${ }^{\circ} \mathrm{C}$, then aldehyde 18 (35 mg, $\left.0.057 \mathrm{mmol}\right)$ was added as a solution in $\mathrm{CH}_{2} \mathrm{Cl}_{2}(150 \mu \mathrm{L}+100 \mu \mathrm{L}$ wash) and the reaction mixture was stirred at $-78{ }^{\circ} \mathrm{C}$ for $18.5 \mathrm{~h}$. After this time, the reaction solution was warmed to $0{ }^{\circ} \mathrm{C}$, quenched by the sequential addition of $\mathrm{pH} 7$ buffer $(600 \mu \mathrm{L}), \mathrm{MeOH}(600 \mu \mathrm{L})$ and $35 \% \mathrm{H}_{2} \mathrm{O}_{2}(300 \mu \mathrm{L})$ and stirred for $1 \mathrm{~h}$. The mixture was extracted with $\mathrm{CH}_{2} \mathrm{Cl}_{2}$ and the combined extractions were dried $\left(\mathrm{Na}_{2} \mathrm{SO}_{4}\right)$ and filtered. Concentration of the filtrate under reduced pressure and purification of the crude mixture via column chromatography $\left(\mathrm{SiO}_{2}, 5: 1 \rightarrow 3: 1\right.$ hexanes:EtOAc) provided 19 (44 mg, 86\%) as a 15:1 mixture of diastereomers. Analysis of the crude reaction mixture by ${ }^{1} \mathrm{H}$ NMR indicated that the reaction proceeded with 13:1 diastereoselectivity. This mixture was used without separation in the next step. The reported ${ }^{1} \mathrm{H}$ and ${ }^{13} \mathrm{C}$ NMR data are for the major diastereomer only: $[\square]_{\mathrm{D}}{ }^{27.0}+22.1\left(\mathrm{c} 0.67, \mathrm{CH}_{2} \mathrm{Cl}_{2}\right) ;{ }^{1} \mathrm{H}$ NMR (500 MHz, $\left.\mathrm{CDCl}_{3}\right) \square 7.37-7.24(\mathrm{~m}, 7 \mathrm{H}), 6.86(\mathrm{~m}, 2 \mathrm{H})$, $6.07(\mathrm{~m}, 1 \mathrm{H}), 5.27(\mathrm{~d}, \mathrm{~J}=3.0 \mathrm{~Hz}, 1 \mathrm{H}), 5.037-5.00(\mathrm{~m}, 2 \mathrm{H}), 4.87(\mathrm{~d}, \mathrm{~J}=11.0 \mathrm{~Hz}, 1 \mathrm{H}), 4.80(\mathrm{~A}$ of $\mathrm{AB}$ quartet, $\mathrm{J}=7.0 \mathrm{~Hz}, 1 \mathrm{H}), 4.75(\mathrm{~B}$ of $\mathrm{AB}$ quartet, $\mathrm{J}=7.0 \mathrm{~Hz}, 1 \mathrm{H}), 4.66(\mathrm{ddt}, \mathrm{J}=10.0,6.5,4.0 \mathrm{~Hz}, 1 \mathrm{H})$, 4.17-4.10 (m, 5H), $3.79(\mathrm{~s}, 3 \mathrm{H}), 3.57(\mathrm{dd}, \mathrm{J}=8.0,3.5 \mathrm{~Hz}, 1 \mathrm{H}), 3.43(\mathrm{~s}, 3 \mathrm{H}), 3.35(\mathrm{dd}, \mathrm{J}=8.5,3.5 \mathrm{~Hz}$, $1 \mathrm{H}), 3.28(\mathrm{~s}, 3 \mathrm{H}), 3.26(\mathrm{~m} \mathrm{1H}), 3.16(\mathrm{~d}, \mathrm{~J}=5.0 \mathrm{~Hz}, 1 \mathrm{H}), 2.81(\mathrm{dd}, \mathrm{J}=13.5,9.5 \mathrm{~Hz}, 1 \mathrm{H}), 1.90(\mathrm{~m}, 3 \mathrm{H})$, $1.69(\mathrm{~m}, 1 \mathrm{H}), 1.12(\mathrm{~s}, 3 \mathrm{H}), 1.10(\mathrm{~s}, 3 \mathrm{H}), 0.99(\mathrm{t}, \mathrm{J}=8.0 \mathrm{~Hz}, 9 \mathrm{H}), 0.91$ (t, J = 8.0 Hz, 9H), 0.64 (q, J = $8.0 \mathrm{~Hz}, 6 \mathrm{H}), 0.54(\mathrm{qd}, \mathrm{J}=8.0,4.0 \mathrm{~Hz}, 6 \mathrm{H}) ;{ }^{13} \mathrm{C} \mathrm{NMR}\left(125 \mathrm{MHz}, \mathrm{CDCl}_{3}\right) \square 170.6,158.8,153.1,145.6$, 135.2, 131.3, 129.4, 128.92, 128.89, 127.3, 113.4, 111.3, 97.1, 90.3, 79.5, 78.6, 75.5, 73.2, 69.7, 69.1, $66.4,56.5,56.2,55.5,55.1,41.5,40.6,37.4,37.3,25.0,7.0,6.9,5.1,5.0$; IR (thin film, $\mathrm{NaCl}$ ) 3493 , 2955, 2877, 1784, 1711, 1614, 1515, 1456, 1387, 1350, 1247, 1153, 1099, 1050, 1012, 916, 823, 742 $\mathrm{cm}^{-1}$; HRMS (ESI) $910.4945 \mathrm{~m} / \mathrm{z}$ [calc $\left.\mathrm{M}+\mathrm{Na}^{+} \mathrm{C}_{47} \mathrm{H}_{77} \mathrm{NaO}_{11} \mathrm{Si}_{2} 910.4933\right]$.

Assignment of the C(3) stereochemistry of 19 by application of the Rychnovsky method: ${ }^{7}$ A small portion of compound 19 was dissolved in equal volumes of $\mathrm{CH}_{2} \mathrm{Cl}_{2}$ and 2,2-dimethoxypropane (ca $300 \mu \mathrm{L}$ each). Two drops of $\mathrm{MeOH}$ were added followed by a catalytic amount of PPTS and the reaction mixture was stirred for $7 \mathrm{~h}$. The reaction was diluted with $\mathrm{Et}_{2} \mathrm{O}$, washed with saturated $\mathrm{NaHCO}_{3}$ and brine, dried $\left(\mathrm{MgSO}_{4}\right)$ and concentrated under reduced pressure to afforded the 1,3acetonide having ${ }^{13} \mathrm{C} \mathrm{NMR}$ data that is consistent with the indicated 1,3-anti stereochemistry.

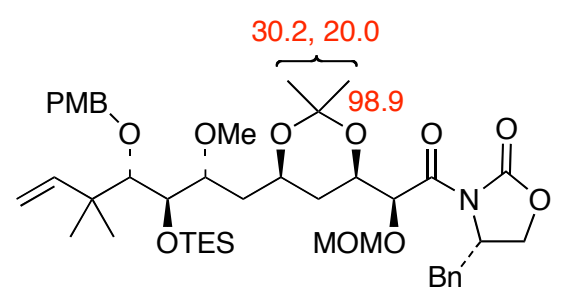




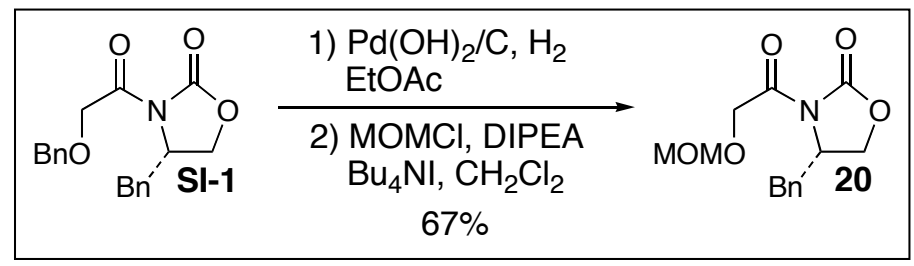

Oxazolidinone 20: O-Benzyl protected glycolate SI-1 (5.10 mmol, $1.66 \mathrm{~g})$ was dissolved in EtOAc $(100 \mathrm{~mL}) \cdot \mathrm{Pd}(\mathrm{OH})_{2} / \mathrm{C}(360 \mathrm{mg})$ was added and the reaction mixture was placed under an atmosphere of hydrogen (balloon pressure) for $3.5 \mathrm{~h}$. The suspention was filtered through Celite and the filtrate concentrated under reduced pressure. The resulting oil was dissolved in $\mathrm{CH}_{2} \mathrm{Cl}_{2}(50 \mathrm{~mL})$ and $\mathrm{Bu}_{4} \mathrm{NI}(65 \mathrm{mg}$, ca $0.1 \mathrm{mmol})$, DIPEA $(5.8 \mathrm{~mL}, 20 \mathrm{mmol})$ and $\mathrm{MOMCl}(960 \mu \mathrm{L}, 12.7 \mathrm{mmol})$ were added sequentially. This mixture was stirred for $18 \mathrm{~h}$, then $\mathrm{NaHCO}_{3}$ was added to the reaction and the aqueous layer extracted with $\mathrm{CH}_{2} \mathrm{Cl}_{2}$. The combined organic washes were dried $\left(\mathrm{MgSO}_{4}\right)$, filtered and concentrated under pressure. Purification of the crude reaction mixture via column chromatography $\left(\mathrm{Si}_{2} \mathrm{O}, 2: 1\right.$ hexanes:EtOAc) provided glycolate $20(956 \mathrm{mg}, 67 \%)$ as an oil: $[\square]_{\mathrm{D}}{ }^{27.0}+73.7$ (c 1.90 , $\left.\mathrm{CH}_{2} \mathrm{Cl}_{2}\right) ;{ }^{1} \mathrm{H}$ NMR (500 MHz, $\left.\mathrm{CDCl}_{3}\right) \square 7.37-7.21$ (m, 5H), 4.79 (d, J = 1.0 Hz, 2H), 4.78 (s, 2H), 4.70 $(\mathrm{ddt}, \mathrm{J}=11.0,8.0,3.5 \mathrm{~Hz}, 1 \mathrm{H}), 4.30\left(\mathrm{~A}\right.$ of $\left.\mathrm{ABX}, \mathrm{J}_{\mathrm{AB}}=9.0 \mathrm{~Hz}, \mathrm{~J}_{\mathrm{AX}}=8.0 \mathrm{~Hz}, 1 \mathrm{H}\right), 4.25(\mathrm{~B}$ of $\mathrm{ABX}$, $\left.\mathrm{J}_{\mathrm{AB}}=9.0 \mathrm{~Hz}, \mathrm{~J}_{\mathrm{BX}}=3.0 \mathrm{~Hz}, 1 \mathrm{H}\right), 3.44(\mathrm{~s}, 3 \mathrm{H}), 3.34(\mathrm{dd}, \mathrm{J}=13.5,3.0 \mathrm{~Hz}, 1 \mathrm{H}), 2.83(\mathrm{dd}, \mathrm{J}=13.5,9.5$ $\mathrm{Hz}, 1 \mathrm{H}) ;{ }^{13} \mathrm{C} \mathrm{NMR}\left(125 \mathrm{MHz}, \mathrm{CDCl}_{3}\right) \square 170.0,153.3,134.9,129.4,129.0,127.4,96.4,67.2$, 66.6, 55.8, 57.8, 37.7; IR (thin film, NaCl) 3029, 2953, 2932, 2826, 1781, 1716, 1498, 1480, 1393, 1352, 1266, 1214, 1152, 1124, 1063, 1021, 978, 937, 920, 763, 732, $702 \mathrm{~cm}^{-1}$; HRMS (ESI) $302.1006 \mathrm{~m} / \mathrm{z}$ [calc $\left.\mathrm{M}+\mathrm{Na}^{+} \mathrm{C}_{14} \mathrm{H}_{17} \mathrm{NO}_{5} \mathrm{Na} 302.1004\right]$.

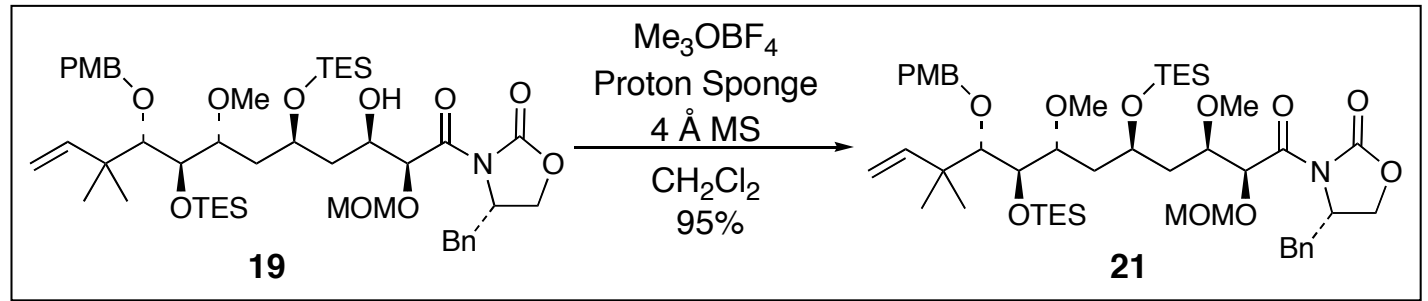

Methyl Ether 21: Alcohol 19 (62 mg, $0.070 \mathrm{mmol})$ was dissolved in $\mathrm{CH}_{2} \mathrm{Cl}_{2}(700 \mu \mathrm{L})$. To this solution were added $4 \AA$ molecular sieves (freshly activated under vacuum, ca. $10 \mathrm{mg}$ ), Proton Sponge (105 mg, $0.490 \mathrm{mmol})$ and $\mathrm{Me}_{3} \mathrm{OBF}_{4}(50 \mathrm{mg}, 0.35 \mathrm{mmol})$. The suspension was stirred for $2 \mathrm{~h}$, diluted with EtOAc and filtered. The filtrate was washed with water, $0.5 \mathrm{M} \mathrm{NaHSO}_{4}(\mathrm{pH}=2.7)$, saturated $\mathrm{NaHCO}_{3}$ and brine and then dried $\left(\mathrm{MgSO}_{4}\right)$. Concentration of the filtered solution under reduced pressure and purification of the resulting mixture via column chromatography $\left(\mathrm{SiO}_{2}, 7: 1\right.$ 
hexanes:EtOAc) provided methyl ether 21 (60 mg, 95\%) as a clear oil ( $\mathrm{dr} 18: 1)$. This mixture was used without separation in the next step. The reported ${ }^{1} \mathrm{H}$ and ${ }^{13} \mathrm{C}$ NMR data are for the major diastereomer only: [ []$_{\mathrm{D}}{ }^{27.0}+50.0$ (c 2.09, $\mathrm{CH}_{2} \mathrm{Cl}_{2}$ ); ${ }^{1} \mathrm{H}$ NMR (500 MHz, $\left.\mathrm{CDCl}_{3}\right) \square 7.37-7.25$ (m, 7H), 8.68 (m, 2H), $6.06(\mathrm{dd}, \mathrm{J}=17.5,11.0 \mathrm{~Hz}, 1 \mathrm{H}), 5.47$ (d, J = 4.0 Hz, 1H), 5.00 (m, 2H), 4.90 (d, J = 11.0 Hz, 1H), 4.79 (A of AB quartet, $\mathrm{J}=7.0 \mathrm{~Hz}, 1 \mathrm{H}), 4.70(\mathrm{~B}$ of $\mathrm{AB}$ quartet, $\mathrm{J}=7.0 \mathrm{~Hz}, 1 \mathrm{H}), 4.57(\mathrm{~m}, 1 \mathrm{H}), 4.40(\mathrm{~d}, \mathrm{~J}=$ $11.0 \mathrm{~Hz}, 1 \mathrm{H}), 4.13(\mathrm{~m}, 4 \mathrm{H}), 3.78(\mathrm{~s}, 3 \mathrm{H}), 3.68(\mathrm{~d}, \mathrm{~J}=10.5 \mathrm{~Hz}, 1 \mathrm{H}), 3.60$ (ddd, J = 10.5, 4.5, 2.0 Hz, 1H), 3.39 (s, 3H), 3.38 (s, 3H), $3.38(\mathrm{~m}, 1 \mathrm{H}), 3.29$ (s, 3H), 3.24 (d, J = 3.0 Hz, 1H), 2.79 (dd, J = 13.5, $10.0 \mathrm{~Hz}, 1 \mathrm{H}), 1.85(\mathrm{~m}, 2 \mathrm{H}), 1.72(\mathrm{ddd}, \mathrm{J}=14.5,11.5,1.5 \mathrm{~Hz}, 1 \mathrm{H}), 1.58(\mathrm{~m}, 1 \mathrm{H}), 1.11(\mathrm{~s}, 3 \mathrm{H}), 1.10(\mathrm{~s}$, $3 \mathrm{H}), 0.99(\mathrm{t}, \mathrm{J}=8.0 \mathrm{~Hz}, 9 \mathrm{H}), 0.94(\mathrm{t}, \mathrm{J}=8.0 \mathrm{~Hz}, 9 \mathrm{H}), 0.65$ (q, J = 8.0 Hz, 6H), 0.59 (qd, J = 8.0, 3.0 $\mathrm{Hz}, 6 \mathrm{H}) ;{ }^{13} \mathrm{C} \mathrm{NMR}\left(125 \mathrm{MHz}, \mathrm{CDCl}_{3}\right) \square 171.0,158.7,153.1,145.9,135.3,131.5,129.5,128.9,127.3$, 113.4, 111.2, 97.3, 90.0, 79.1, 78.8, 76.9, 75.1, 73.3, 66.5, 66.3, 59.5, 56.7, 56.1, 55.7, 55.2, 41.6, 40.6, 37.5, 37.0, 25.4, 24.3, 7.1, 7.0, 5.3, 5.1; IR (thin film, NaCl) 954, 2934, 2876, 1785, 1709, 1613, 1514, 1456, 1415, 1387, 1349, 1301, 1247, 1194, 1154 1103, 1052, 1010, 917, 827, 743, 668.2 cm ${ }^{-1}$; HRS (ESI) $924.5115 \mathrm{~m} / \mathrm{z}$ [calc $\left.\mathrm{M}+\mathrm{Na}^{+} \mathrm{C}_{48} \mathrm{H}_{79} \mathrm{NaO}_{11} \mathrm{Si}_{2} 924.5089\right]$.

Determination of enantiomeric purity for major diastereomer: The mixture of diastereomers isolated above was purified via HPLC (85:15 hexanes:EtOAc). The major diastereomer was then dissolved in $2: 1 \mathrm{CH}_{2} \mathrm{Cl}_{2}: \mathrm{MeOH}(\mathrm{ca} .500 \mu \mathrm{L}$ ) and the solution was treated with a catalytic PPTS until both TES-groups were cleaved as determined by TLC analysis. The reaction was quenched with $\mathrm{Et}_{3} \mathrm{~N}$ and concentrated. The crude material was dissolved in $\mathrm{Et}_{2} \mathrm{O}$ and the organic layer washed with water, saturated $\mathrm{NaHCO}_{3}$ and brine and dried $\left(\mathrm{MgSO}_{4}\right)$. After concentration, the resulting material was dissolved in pyridine (ca. $400 \mu \mathrm{L}$ ), the solution was spit into two vials and treated an excess of either $(S)$ - or $(R)$-MTPA-Cl. After the reaction was complete, each reaction was diluted with $\mathrm{Et}_{2} \mathrm{O}$ and washed with water, saturated $\mathrm{NaHCO}_{3}$ and brine and dried $\left(\mathrm{MgSO}_{4}\right)$. Analysis of the crude products by ${ }^{1} \mathrm{H}$ NMR indicated that the \% e.e. of the major diastereomer was $>95 \%$ (the minor diastereomer was not detected in the ${ }^{1} \mathrm{H}$ NMR spectra).

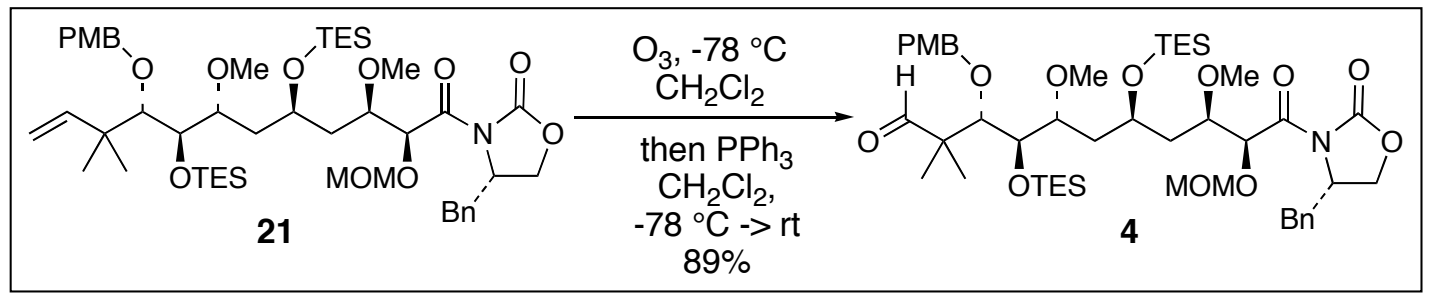

Aldehyde 4: Alkene $21(77 \mathrm{mg}, 0.085 \mathrm{mmol})$ was dissolved in $\mathrm{CH}_{2} \mathrm{Cl}_{2}(1 \mathrm{~mL})$ and the solution was cooled to $-78{ }^{\circ} \mathrm{C}$. A stream of ozone was bubbled through the solution until it turned blue. Solid 
triphenylphosphine (45 $\mathrm{mg}, 0.17 \mathrm{mmol}$ ) was then added, and the reaction mixture was warmed to room temperature and stirred for $3 \mathrm{~h}$. The solution was concentrated under reduced pressure and the resulting oil was separated via column chromatography $\left(\mathrm{SiO}_{2}, 5: 1\right.$ hexanes:EtOAc) provided aldehyde $4(68 \mathrm{mg}, 89 \%)$ as a cloudy oil (dr 18:1). Purification of the mixture of diastereomers by HPLC (78:22

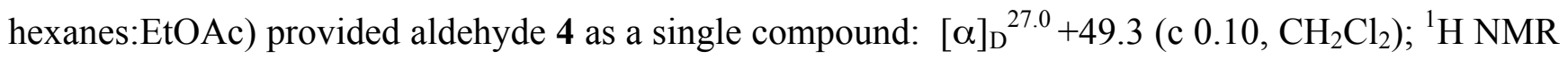
$\left(500 \mathrm{MHz}, \mathrm{CDCl}_{3}\right) \square 9.46(\mathrm{~s}, 1 \mathrm{H}), 7.36(\mathrm{~m}, 2 \mathrm{H}), 7.31-7.26(\mathrm{~m}, 5 \mathrm{H}), 6.88(\mathrm{~m}, 2 \mathrm{H}), 5.53(\mathrm{~d}, \mathrm{~J}=4.5 \mathrm{~Hz}$, 1H), $4.80(\mathrm{~d}, \mathrm{~J}=10.5 \mathrm{~Hz}, 1 \mathrm{H}), 4.80(\mathrm{~d}, \mathrm{~J}=7.0 \mathrm{~Hz}, 1 \mathrm{H}), 4.71(\mathrm{~d}, \mathrm{~J}=6.5 \mathrm{~Hz}, 1 \mathrm{H}), 4.65$ (ddt, J = 9.5, 6.5, $3.0 \mathrm{~Hz}, 1 \mathrm{H}), 4.66(\mathrm{~d}, \mathrm{~J}=11.0 \mathrm{~Hz}, 1 \mathrm{H}), 4.17(\mathrm{~m}, 3 \mathrm{H}), 4.00(\mathrm{~d}, \mathrm{~J}=8.0 \mathrm{~Hz}, 1 \mathrm{H}), 3.81(\mathrm{~s}, 3 \mathrm{H}), 3.64-3.57$ $(\mathrm{m}, 3 \mathrm{H}), 3.41(\mathrm{~s}, 6 \mathrm{H}), 3.40(\mathrm{~s}, 3 \mathrm{H}), 3.36(\mathrm{dd}, \mathrm{J}=10.5,7.0 \mathrm{~Hz}, 1 \mathrm{H}), 2.81(\mathrm{dd}, \mathrm{J}=13.0,9.5 \mathrm{~Hz}, 1 \mathrm{H})$, $1.98(\mathrm{ddd}, \mathrm{J}=13.5,11.0,2.0 \mathrm{~Hz}, 1 \mathrm{H}), 1.80(\mathrm{~m}, 1 \mathrm{H}), 1.72(\mathrm{~m}, 1 \mathrm{H}), 1.57(\mathrm{dd}, \mathrm{J}=13.5,10.0 \mathrm{~Hz}, 1 \mathrm{H})$, $1.15(\mathrm{~s}, 3 \mathrm{H}), 1.08(\mathrm{~s}, 3 \mathrm{H}), 0.95(\mathrm{t}, \mathrm{J}=8.0 \mathrm{~Hz}, 6 \mathrm{H}), 0.91(\mathrm{t}, \mathrm{J}=8.0 \mathrm{~Hz}, 6 \mathrm{H}), 0.66(\mathrm{~m}, 9 \mathrm{H}), 0.57(\mathrm{dq}, \mathrm{J}=$ 7.5, $3.5 \mathrm{~Hz}, 9 \mathrm{H}) ;{ }^{13} \mathrm{C} \mathrm{NMR}\left(125 \mathrm{MHz}, \mathrm{CDCl}_{3}\right) \square 202.2,170.6,158.8,152.9,135.0,130.2,129.2$, $128.7,128.2$, 127.1, 113.4, 97.0, 83.0, 78.9, 78.6, 75.9, 74.3, 73.1, 66.2, 66.1, 59.2, 57.0, 55.9, 55.5, 55.0, 49.9, 40.0, 37.2, 36.3, 21.3, 15.7, 6.78, 6.7, 5.0, 4.7; IR (thin film, NaCl) 2955, 2877, 2834, 2717, $1784,1722,1711,1614,1586,1498,1515,1457,1388,1349,1302,1248,1211,1195,1154,1104$, 1050, 1008, 920, 894, 855, 821, 794, 748, $702 \mathrm{~cm}^{-1}$; HRMS (ESI) $926.4899 \mathrm{~m} / \mathrm{z} \quad$ [calc $\mathrm{M}+\mathrm{Na}^{+}$ $\left.\mathrm{C}_{47} \mathrm{H}_{77} \mathrm{NaO}_{12} \mathrm{Si}_{2} 926.4882\right]$. 